\title{
Radioprotective Effect of Sodium Selenite on Bone Repair in the Tibia of Ovariectomized Rats
}

\author{
Deborah Queiroz de FREITAS ${ }^{1}$ \\ Flávia Maria de Moraes RAMOS-PEREZ ${ }^{2}$ \\ Ellen Gaby NEVES ${ }^{1}$ \\ Marcelo Rocha MARQUES ${ }^{3}$ \\ Frab Norberto BÓSCOLO ${ }^{1}$ \\ Solange Maria de ALMEIDA ${ }^{1}$ \\ ${ }^{1}$ Oral Radiology Area, Department of Oral Diagnosis, Piracicaba Dental School, \\ UNICAMP - University of Campinas, Piracicaba, SP, Brazil \\ ${ }^{2}$ Department of Clinical and Preventive Dentistry, UFPE - Federal University of Pernambuco, Recife, PE, Brazil \\ ${ }^{3}$ Department of Morphology, Division of Histology, Piracicaba Dental School, \\ UNICAMP - University of Campinas, Piracicaba, SP, Brazil
}

\begin{abstract}
This study evaluated protection by selenium (Se) in the bone repair process in ovariectomized rats after irradiation. For such purpose, 80 ovariectomized female Wistar rats were randomly divided into 4 experimental groups: ovariectomized (Ov), Ov/Se, Ov/irradiated (Irr) and Ov/ Se/Irr. A bone defect was created on the tibia of all animals 40 days after ovariectomy. Two days after surgery, only the $\mathrm{Ov} / \mathrm{Se}$ and $\mathrm{Ov} / \mathrm{Se} / \mathrm{Irr}$ rats received $0.8 \mathrm{mg} \mathrm{Se} / \mathrm{kg}$. Three days after surgery, only the Ov/Irr and Ov/Se/Irr rats received $10 \mathrm{~Gy}$ of $\mathrm{x}$-rays on the lower limb region. The animals were euthanized at 7, 14, 21 and 28 days after surgery to assess the repair process, which was evaluated by analysis of trabecular bone number (Masson Trichrome) and birefringence analysis (Picrosirius). It was possible to observe a delay in the bone repair process in the ovariectomized/irradiated group and similarity between the ovariectomized, Ov/ $\mathrm{Se}$ and $\mathrm{Ov} / \mathrm{Se} / \mathrm{Irr}$ groups. In conclusion, sodium selenite exerted a radioprotective effect in the bone repair of tibia of ovariectomized rats without toxicity.
\end{abstract}

Key Words: radiotherapy, osteoporosis, selenium, ovariectomy.

\section{INTRODUCTION}

Bone is a metabolically active tissue and its activity is essential to maintain tissue integrity and body homeostasis. Estrogen is involved in the bone remodeling process and it is responsible for the balance between resorption and bone formation. The ovaries are a major source of estrogen and loss of the ovarian function results in a reduction of the endocrine hormones that maintain skeletal mass (1). The adverse effects resulting from estrogen deficiency caused by either postmenopausal or surgical procedures are a major concern. Rat skeleton is a widely used model in preclinical research on osteoporosis $(1,2)$. Ovariectomy is associated with similar histological changes in rat and human bone, and it can thus provide beneficial information on human postmenopausal bone loss.

Malignant lesions are mainly treated by a combination of surgical and radiation procedures. Ionizing radiation is mainly used for diagnostic and therapeutic purposes, but its application often results in deleterious effects (3-6) due to the formation of free radicals, which are highly reactive, removing hydrogen atoms from fatty acids, causing lipid peroxidation and consequently cell death.

The combination of estrogen deficiency and radiation results in a decrease in the formation of newly formed bone, thus accelerating the resorption process (5). Therefore, healing after trauma may be compromised in irradiated and fragile bones.

Correspondence: Profa. Dra. Deborah Q. Freitas, Área de Radiologia Oral, Departamento de Diagnostico Oral, Faculdade de Odontologia de Piracicaba, UNICAMP, Avenida Limeira, 901, Areião, 13414-400 Piracicaba, SP, Brasil. Tel: +55-19-2106-5329. Fax: +55-19-2106-5327. e-mail: deborah@fop.unicamp.br 
Radioprotective agents have been developed to minimize these deleterious effects in normal tissues. These agents may eliminate the free radicals, acting as sweepers or, in an indirect manner, increasing antioxidant enzymes such as peroxidase glutathione. Selenium (Se) has been indicated as a component of this enzyme, which provides it a radioprotective action (7). Thus, it is extremely important to evaluate the action of radioprotective agents on tissue repair because the combination of surgery and radiotherapy is still used for the treatment of some types of tumors.

Because osteoporosis causes bone fragility, ionizing radiation causes difficulties in the process of bone repair, which may occur in individuals with estrogen deficiency who are submitted to radiotherapy, the aim of the present study was to investigate whether administration of sodium selenite can reduce the radiation-induced damage in the bone repair process in ovariectomized rats.

\section{MATERIAL AND METHODS}

Eighty female adult Wistar rats were used and randomly assigned to 4 groups $(\mathrm{n}=20)$ according to the treatment: (a) ovariectomized (Ov), in which bilateral ovariectomy was performed; (b) ovariectomized/ irradiated (Ov/Irr), in which bilateral ovariectomy was performed before the irradiation procedure; (c) ovariectomized/selenium $(\mathrm{Ov} / \mathrm{Se})$, in which ovariectomized rats received an intraperitoneal injection of $0.8 \mathrm{mg} / \mathrm{kg}$ sodium selenite (Merck KgaA, Darmstadt, Germany) diluted in distilled water $24 \mathrm{~h}$ before sham irradiation; (d) ovariectomized/selenium/irradiated $(\mathrm{Ov} / \mathrm{Se} / \mathrm{Irr})$, in which ovariectomized rats received an intraperitoneal injection of $0.8 \mathrm{mg} / \mathrm{kg}$ sodium selenite diluted in distilled water $24 \mathrm{~h}$ before the irradiation with $\mathrm{x}$-rays. Ovariectomy success was evaluated by observing marked atrophy of the uterine horns in the rats.

Forty days after the ovariectomy, the animals were weighed and anesthetized with an intramuscular injection of ketamine chlorhydrate $(0.1 \mathrm{mg} / \mathrm{kg})$ in order to create a bone defect on the tibia for evaluation of bone tissue repair. For this, a bore hole was drilled into both tibial cortical bones of all animals using a size 8 carbide bur (KG Sorensen, São Paulo, SP, Brazil) at low speed under saline irrigation, to create a $3 \times 1.5 \times 0.5$ $\mathrm{mm}$ defect on the bone surface.

Two days after the bone defect procedure (24 $\mathrm{h}$ before the irradiation), the rats belonging to the $\mathrm{Ov} /$
$\mathrm{Se}$ and $\mathrm{Ov} / \mathrm{Se} / \mathrm{Irr}$ groups received an intraperitoneal injection of $0.8 \mathrm{mg} / \mathrm{kg}$ sodium selenite diluted in distilled water. The animals in the other groups received only distilled water.

Three days after the bone defect procedure (24 $\mathrm{h}$ after the Se injection), the animals were anesthetized once more with the same drug, and those in the Ov/Irr and $\mathrm{Ov} / \mathrm{Se} / \mathrm{Irr}$ groups received a single acute exposure of $10 \mathrm{~Gy}$ of X-radiation (Varian, Clinic 6/100, $100 \mathrm{~cm}$ source-target distance, and $15 \times 30 \mathrm{~cm}$ field) in the lower limb region. The Ov and $\mathrm{Ov} / \mathrm{Se}$ animals were anesthetized, but not irradiated.

Specimens were obtained 7, 14, 21 and 28 days after the bone defect surgery. The tibias were removed and placed in $10 \%$ formaldehyde buffer for $72 \mathrm{~h}$. The bone specimens were then dehydrated in 5\% EDTA (Titriplex III, ACS, ISO; Merck, Darmstadt, Germany) embedded in paraffin, longitudinally sectioned (5$\mu \mathrm{m}$ thick) and stained with Masson's Trichrome and Picrosirius. In order to assess the area density of the bone surface, 3 measures were made in different areas, one of which was in the middle of the bone defect and the others beside it. The specimens were observed with an optical microscope $(\times 40)$, using a reticulum with 100 points in Masson Trichrome stain. For birefringence analysis, Picrosirius stained specimens were digitized using a polarized light microscope $(\times 10)$ (Axiolab; Zeiss, Berlin, Germany) and a microcamera (CCD/ RGB Color Sony, Tokyo, Japan). Measurements in the middle of the bone defect were made using an analytical system (KS 400 2.0; Kontron Elektronics, Munich, Germany).

Data were initially evaluated using ANOVA and significant differences were resolved by the Tukey's test, with a significant $p$ value $<0.05$.

This study was approved by the Ethics Commission on Animal Experimentation of the State University of Campinas (Protocol \#1239-2).

\section{RESULTS}

\section{Quantitative Evaluation of Bone Tissue Area Density}

The mean area density in the bone tissue on the evaluation days are shown in Table 1 .

At 7 days, it was possible to observe that the Ov/ Se group presented the highest value $(\mathrm{p}<0.05)$, followed by the $\mathrm{Ov} / \mathrm{Se} / \mathrm{Irr}$ and $\mathrm{Ov}$ groups, and no significant differences were observed between the two last groups 
at that time $(p<0.05)$. The Ov/Irr group showed the lowest value, differing significantly from the other groups ( $\mathrm{p}<0.05)$.

At 14 days, the lowest value was also presented by the Ov/Irr group. Statistically significant differences were found between this group and the others $(p<0.05)$. However, there were no significant differences among the $\mathrm{Ov}, \mathrm{Ov} / \mathrm{Se}$ and $\mathrm{Ov} / \mathrm{Se} / \mathrm{Irr}$ groups $(\mathrm{p}>0.05)$.

At 21 days, the Ov group presented the highest area density value, which was statistically different from the others $(\mathrm{p}<0.05)$. Again, the Ov/Irr group showed the lowest value $(\mathrm{p}<0.05)$. Although the values for the $\mathrm{Ov} / \mathrm{Se}$ and $\mathrm{Ov} / \mathrm{Se} / \mathrm{Irr}$ groups were less than that those of the $\mathrm{Ov}$ group, they were higher than those of the Ov/Irr group.

At 28 days of the repair process, the Ov and $\mathrm{Ov} / \mathrm{Se} / \mathrm{Irr}$ groups presented similar values, which were statistically different from the other two groups.

\section{Quantitative Evaluation of the Area of Collagen Fibers by Picrosirius Staining}

Table 2 presents the means of values for the area of collagen fibers at the evaluated times.

At 7 days, the $\mathrm{Ov}, \mathrm{Ov} / \mathrm{Se}$ and $\mathrm{Ov} / \mathrm{Se} / \mathrm{Irr}$ groups presented greater birefringence values and the Ov/Irr group presented the lowest values, differing statistically from the $\mathrm{Ov}$ and $\mathrm{Ov} / \mathrm{Se} / \mathrm{Irr}$ groups $(\mathrm{p}<0.05)$.

After 14 days of the repair process, there was a similar situation; the $\mathrm{Ov}, \mathrm{Ov} / \mathrm{Se}$ and $\mathrm{Ov} / \mathrm{Se} / \mathrm{Irr}$ groups presented higher values and the Ov/Irr group presented the lowest values, differing statistically from the other three groups $(\mathrm{p}<0.05)$.

At 21 days, the highest mean birefringence was found in the Ov/Se/Irr group, which was significantly different from the other three groups $(\mathrm{p}<0.05)$. No statistically significant differences were observed between the Ov and Ov/Se groups ( $>0.05)$, but significant differences were found between the $\mathrm{Ov} / \mathrm{Irr}$ group and the others.

After 28 days of the repair process, the $\mathrm{Ov} / \mathrm{Se} /$ Irr group still had the highest value, however it was not significantly different from the Ov group $(p>0.05)$; significant differences were found between the Ov/Irr group and the others $(\mathrm{p}<0.05)$.

\section{DISCUSSION}

\begin{tabular}{lcccc}
\hline $\begin{array}{l}\text { Time } \\
\text { (days })\end{array}$ & Ov & Ov/Irr & Ov/Se & Ov/Se/Irr \\
\hline 7 & $2412.1(264.8)^{\mathrm{A}}$ & $1730.7(91.64)^{\mathrm{B}}$ & $2084.2(107.07)^{\mathrm{AB}}$ & $2349.2(129.26)^{\mathrm{A}}$ \\
14 & $2940.2(257.92)^{\mathrm{A}}$ & $1644.3(222.24)^{\mathrm{B}}$ & $2699.1(178.43)^{\mathrm{A}}$ & $2884.7(268.81)^{\mathrm{A}}$ \\
21 & $1721.1(128.82)^{\mathrm{B}}$ & $1256.7(45.51)^{\mathrm{C}}$ & $1867.3(104.40)^{\mathrm{B}}$ & $2243.5(205.04)^{\mathrm{A}}$ \\
28 & $2298.4(124.72)^{\mathrm{AB}}$ & $1887.1(86.31)^{\mathrm{C}}$ & $2196.4(110.05)^{\mathrm{B}}$ & $2431.8(73.05)^{\mathrm{A}}$ \\
\hline
\end{tabular}

Means followed by different letters for each time differ significantly with a significant p-value of $5 \%$ by the Tukey's test.
Bone fracture and some surgical procedures cause a modification in tissue integrity when good healing is necessary for this tissue to exert its normal activities. According to Meyer et al. (8), bone remodeling can be influenced by systemic and 
local factors. Chicarelli et al. (5) observed that a combination of systemic and local factors, such as estrogen deficiency and ionizing radiation, respectively, influenced negatively the bone repair process.

Estrogen is probably the most important hormone responsible for the maintenance of normal bone turnover and consequently the loss of ovarian function in animals and humans causes dramatic and accelerated bone loss $(1,9)$. Ovariectomy in rats is associated with similar histological changes as in human bones and the rat model provides useful information on human bone loss $(1,2)$. Women are more frequently affected by osteoporosis. Severe bone loss is related to the acute effect of estrogen deficiency and aging factors, both contributing to increased bone fragility $(10)$. Several authors $(2,5,9)$ confirmed that individuals with osteoporosis apparently show a diminished capacity to repair and remodel. In this study, the bone defects were created 40 days after ovariectomy in order to induce an osteoporotic bone (11).

There are several studies on the differences between the repair process in healthy bone and in osteoporotic bone $(2,5,8,9)$ using irradiated and nonirradiated bone (3-6) and they have all suggested a diminished capacity of repair and remodeling in ovariectomized and/or irradiated bone compared with control groups. Therefore, in the present study nonovariectomized animals were not include because the aim was to evaluate if Se presented antioxidant proprieties in osteoporotic bone. Thus, the ovariectomized group without Se or irradiation treatment was considered as the control group.

Ionizing radiation is frequently used for the treatment of primary or metastatic bone malignancies. The real mechanism involved in its action on bones is still not fully understood; however, studies have demonstrated that radiation modifies the balance between osteoclastic and osteoblast activity, favoring the destructive process $(12,13)$. According to Gal et al. (14), osteoblast proliferation is inhibited by radiation because there is an attenuated growth rate of irradiated cells and osteoblasts show diminished rates of collagen production. Sakurai et al. (4) suggested that ionizing radiation at therapeutic doses interferes with bone formation by reducing osteoblasts, alkali phosphatase activity and collagen production. Nowadays, it is not uncommon for people with osteoporosis to require diagnostic examinations or therapeutic treatments using ionizing radiation.

Irradiation delivered 3 days after a surgical procedure was also chosen by Chicarelli et al. (5) and Rocha et al. (6) because the immediate post-surgery period is one of the most critical repair phases and radiation may cause severe alterations in bone and its capacity to react to trauma. High radiation doses, such as 8 Gy of gamma rays, used by those authors affected the bone repair process. This could explain the delay in the repair process in the radiation group for all evaluation times, since a 10 Gy dose was used.

The antioxidant properties of most Se derivatives, including sodium selenite, are widely known and the radioprotective action of sodium selenite has been demonstrated in several tissues, such as human skin cells (15), gastrointestinal epithelium (16), salivary glands (17), kidneys (18) and even healthy bone (6), but not in osteoporotic bone. According to Stewart et al. (7), the antioxidant action of $\mathrm{Se}$ is related to its ability to inhibit peroxidation, catch free radicals and repair molecular damage. All these functions seem to be related to a known antioxidant enzyme: peroxidase glutathione.

After the surgical procedure, the normal bone architecture is lost, and so a large number of free radicals are released. The radiation also produces such radicals. The Se group presented features and values of bone density and birefringence closer to or higher than those of the control group, represented by the Ov group in this study, at all experimental periods, emphasizing its antioxidant mechanisms. Such antioxidant proprieties can be confirmed by observing the values for the Ov/ $\mathrm{Se} / \mathrm{Irr}$ group, which were closer to the control group at all periods evaluated except at 21 days. Although the value for the $\mathrm{Ov} / \mathrm{Se} / \mathrm{Irr}$ was lower than that of the Ov group, it was higher than the Ov/Irr group for bone density, which is beneficial for bone repair. Moreover, in the birefringence analysis, the value for the $\mathrm{Ov} / \mathrm{Se} / \mathrm{Irr}$ group was higher than that of the control group.

Bone repair took place at the expected times. The formation of bone trabeculae was observed 7 days after the preparation of the bone defects. At 14 days, the bone area was increased due to bony callus formation. The total area of bone at 21 days decreased but the bone density increased. At 28 days, the bone density was similar to that at 21 days, but the total area of cortical bone was thicker. This pattern was observed in all groups; however, the Ov/Irr group was always slower than the others. The difference between the values for Ov/Irr group and the other groups was higher in the initial periods, which demonstrates that the radiation caused more effects at the beginning of the repair process. 
The values for birefringence were also compatible with bone repair. The highest values were observed at 14 days, when there was a large area of bony callus and consequently a greater amount of collagen. The values decreased subsequently. The relationship between birefringence and bone density is directly proportional. A greater value of birefringence means more collagen fibers and consequently greater values for bone trabeculae, which is represented by the area density. Generally, the groups with the highest birefringence values also had the highest values for area density.

Several studies reported toxicity with high doses of Se (18-21). Thus, despite the radioprotective action, the possibility of sodium selenite causing adverse effects should not be dismissed. In the present study, it was not possible to detect toxicity in the experimental periods.

According to Jakob et al. (22), the expression of reductase thioredoxin and other selenoproteins in bone cells is an important means of regulation of bone resorption and remodeling. Sandukji et al. (23) reported that the osteocalcin level and the activity of alkaline phosphatase were markedly increased in the plasma of patients who received antioxidants (vitamins A, E, and $\mathrm{C}$ in addition to $\mathrm{Se}$ ) for 2 weeks after surgery on long bones; they concluded that administration of antioxidants could accelerate bone healing.

There are some limitations to a study using lab animals instead of humans, although the rat model provides useful information on human bone loss. For this reason, the results obtained in the present study provide important data for the evaluation of sodium selenite effects on the repair of osteoporotic irradiated bone, but a careful analysis of the results is necessary. Some studies with Se have also been conducted in patients with cancer who required radiotherapy. Buntzel et al. (24) found that Se might be able to reduce the loss of taste sensitivity and dysphagia. However, to the best of our knowledge, the no study in patients with osteoporosis.

It is important to evaluate the risk/benefit of sodium selenite in the process of bone repair in individuals submitting to radiotherapy. In agreement with Rocha et al. (6), it is believed that the possible sequels of radiotherapy entirely justify the use of this radioprotective agent, thus contributing to improved quality of life of patients.

Based on the results of this study, it may be concluded that sodium selenite exerted a radioprotective effect on the bone repair of tibia of ovariectomized rats. In view of the number of studies in this area, more favorable and applicable results are expected, decreasing the alterations caused in healthy tissues of patients treated with radiotherapy and consequently increasing their life quality and expectancy.

\section{RESUMO}

Esse estudo avaliou a proteção do selênio no processo de reparação óssea em ratas ovariectomizadas após irradiação. Para isso, 80 ratas Wistar foram divididas aleatoriamente em 4 grupos experimentais: ovariectomizado, ovariectomizado/selênio, ovariectomizado/irradiado e ovariectomizado/selênio/irradiado. Foi realizado um defeito ósseo na tíbia de todos os animais 40 dias após ovariectomia. Dois dias após essa cirurgia, os animais dos grupos ovariectomizado/selênio e ovariectomizado/selênio/ irradiado receberam $0,8 \mathrm{mg} \mathrm{Se} / \mathrm{kg}$. Três dias após a cirurgia, os animais dos grupos ovariectomizado/irradiado e ovariectomizado/ selênio/irradiado receberam $10 \mathrm{~Gy}$ de radiação $\mathrm{X}$ na região de membros inferiores. Os animais foram sacrificados 7, 14, 21 e 28 dias após a cirurgia para avaliação do processo de reparo ósseo, que foi realizado pela análise do número de trabéculas ósseas (coloração Tricrômico de Masson) e pela análise de birrefringência (coloração de Picrosirius). Foi observado atraso no processo de reparo ósseo no grupo ovariectomizado/irradiado e semelhança entre os grupos ovariectomizado, ovariectomizado/selênio e ovariectomizado/selênio/irradiado. Foi possível concluir que o selenito de sódio exerceu efeito radioprotetor no processo de reparação de tíbias em ratas ovariectomizadas sem toxicidade.

\section{REFERENCES}

1. Comelekoglu U, Bagis S, Yalin S, Ogenler O, Yildiz A, Sahin NO, et al. . Biomechanical evaluation in osteoporosis: ovariectomized rat model. Clin Rheumatol 2007;26:380-384.

2. Iwaniec UT, Yuan D, Power RA, Wronski TJ. Strain-dependent variations in the response of cancerous bone to ovariectomy in mice. J Bone Miner Res 2006;21:1068-1074.

3. Williams HJ, Davies AM. The effect of X-rays on bone: a pictorial review. Eur Radiol 2006;16:619-633.

4. Sakurai T, Sawada Y, Yoshimoto M, Kawai M, Miyakoshi J. Radiation-induced reduction of osteoblast differentiation in C2C12 cells. J Radiat Res 2007;48:515-521.

5. Chicarelli M, Ramos FM, Manzi FR, Novaes PD, Bóscolo FN, Almeida SM. Effect of gamma rays on the bone repair process in rats with estrogen deficiency. Braz Oral Res 2007;21:75-80.

6. Rocha AS, Ramos-Perez FM, Bóscolo FN, Manzi FR, Chicarelo M, Almeida SM. Effect of sodium selenite on bone repair in tibiae of irradiated rats. Braz Dent J 2009;20:186-190.

7. Stewart MS, Spallholz JE, Neldner KH, Pence BC. Selenium compounds have disparate abilities to impose oxidative stress and induce apoptosis. Free Radic Biol Med 1999;26:42-48.

8. Meyer Jr RA, Tsahakis PJ, Martin DF, Banks DM, Harrow ME, Kiebzak GM. Age and ovariectomy impair both the normalization of mechanical properties and the accretion of mineral by the fracture callus in rats. J Orthop Res 2001;19:428-435.

9. Anbinder AL, Prado Fde A, Prado Mde A, Balducci I, da Rocha RF. The influence of ovariectomy, simvastatin and sodium alendronate on alveolar bone in rats. Braz Oral Res 2007;21:247252.

10. Eastell R. Management of osteoporosis due to ovarian failure. Med 
Pediatr Oncol 2003;41:222-227

11. Giardino R, Fini M, Giavaresi G, Mongiorgi R, Gnudi S, Zati A. Experimental surgical model in osteoporosis study. Boll Soc Ital Biol Sper 1993;69:453-460.

12. Dudziak ME, Saadeh PB, Mehrara BJ, Steinbrech DS, Greenwald JA, Gittes GK, et al.. The effects of ionizing radiation on osteoblast-like cells in vitro. Plast Reconstr Surg 2000;106:10491061.

13. Szymczyk KH, Shapiro IM, Adams CS. Ionizing radiation sensitizes bone cells to apoptosis. Bone 2004;34:148-156.

14. Gal TJ, Munoz-Antonia T, Muro-Cacho CA, Klotch DW. Radiation effects on osteoblasts in vitro: a potential role in osteoradionecrosis. Arch Otolaryngol Head Neck Surg 2000;126:1124-1128.

15. Rafferty TS, McKenzie RC, Hunter JAA, Howie AF, Arthur JR, Nicol F, et al.. Differential expression of selenoproteins by human skin cells and protection by selenium from UVB-radiation-induced cell death. Biochem J 1998;332:231-236.

16. Mutlu-Turkoglu U, Erbil Y, Öztezcan S, Olgac V, Toser G, Uysal $M$. The effect of selenium and/or vitamin e treatments on radiationinduced intestinal injury in rats. Life Sci 2000;66:1905-1913.

17. Tuji FM, Pontual ML, Barros SP, Almeida SM, Bóscolo FN. Ultrastructural assessment of the radioprotective effects of sodium selenite on parotid glands in rats. J Oral Sci 2010;52:369-375.

18. Sieber F, Muir SA, Cohen EP, North PE, Fish BL, Irving AA, et al. High-dose selenium for the mitigation of radiation injury: a pilot study in a rat model. Radiat Res 2009;171:368-373.

19. Wu J, Lyons GH, Graham RD, Fenech MF. The effect of selenium, as selenomethionine, on genome stability and cytotoxicity in human lymphocytes measured using the cytokinesis-block micronucleus cytome assay. Mutagenesis 2009;24:225-232.

20. MacFarquhar JK, Broussard DL, Melstrom P, Hutchinson R, Wolkin A, Martin C, et al.. Acute selenium toxicity associated with a dietary supplement. Arch Intern Med 2010;170:256-261.

21. Raines AM, Sunde RA. Selenium toxicity but not deficient or super-nutritional selenium status vastly alters the transcriptome in rodents. BMC Genomics 2011;12:26.

22. Jakob F, Becker K, Paar E, Ebert-Duemig R, Schütze N. Expression and regulation of thioredoxin reductases and other selenoproteins in bone. Methods Enzymol 2002;347:168-179.

23. Sandukji A, Al-Sawaf H, Mohamadin A, Alrashidi Y, Sheweita S. Oxidative stress and bone markers in plasma of patients with long-bone fixative surgery: role of antioxidants. Hum Exp Toxicol 2011;30:435-442.

24. Büntzel J, Micke O, Kisters K, Bruns F, Glatzel M, Schönekaes K, et al.. Selenium substitution during radiotherapy of solid tumours - laboratory data from two observation studies in gynaecological and head and neck cancer patients. Anticancer Res 2010;30:17831786.

Received November 29, 2011

Accepted November 5, 2012 